\title{
A RARE CASE OF AN EXTENSIVE SUBCUTANEOUS NECROSIS IN THE LEFT TEMPORAL REGION CAUSED BY ORANGE OIL INJECTION AND ITS MANAGEMENT
}

\author{
SOL TEMPORAL BÖLGEYE PORTAKAL YAĞI ENJEKSIYONU SONRASI GELIŞEN YAYGIN \\ DERI ALTI NEKROZU OLGUSUNA YAKLAŞIM
}

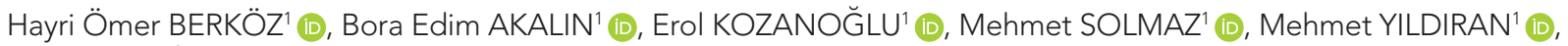 \\ Ufuk EMEKLI'1 (1)
}

${ }^{1}$ Istanbul University, Istanbul Faculty of Medicine, Department of Plastic Reconstructive and Aesthetic Surgery, Istanbul, Turkey

ORCID IDs of the authors: H.Ö.B. 0000-0001-8063-9995; B.E.A. 0000-0002-5654-2082; E.K. 0000-0003-1192-9520;

M.S. 0000-0002-3714-170X; M.Y. 0000-0002-6251-1290; U.E. 0000-0001-9097-5124

Cite this article as: Berkoz HO, Akalin BE, Kozanoglu E, Solmaz M, Yildiran M, Emekli U. A rare case of an extensive subcutaneous necrosis in the left temporal region caused by orange oil injection and its management. J Ist Faculty Med 2022;85(1):130-2.

doi: 10.26650/IUITFD.904638

\section{ABSTRACT}

Orange oil (isoparaffin $\mathrm{C} 11-\mathrm{C} 15)$ is a solvent material that dissolves tooth filling materials effectively. A 29-year-old male who had extensive subcutaneous left temporal necrosis after an inadvertent orange oil injection is presented. Due to the injection, an immediate oedema and cellulitis formed in the left buccal, zygomatic, and temporal region. After a prompt drainage and antibiotherapy, the patient's complaints were resolved. Due to partial temporal muscle necrosis and fibrosis, the interincisal mouth opening (IIO) was 15 millimeters. With a precise physical medicine and rehabilitation regimen, the $\| \mathrm{O}$ became 35 millimeters at the postoperative first year.

Keywords: Drainage, interincisal opening, isoparaffin C11-15, mouth stretching exercise, orange oil

\section{ÖZET}

Portakal yağı (izoparafin C11-C15) diş dolgusu maddelerini etkin şekilde çözen bir kimyasal maddedir. Yanlışlıkla portakal yağı enjeksiyonu sonrası sol temporal bölgesinde yaygın nekroz gelişmiş olan yirmi dokuz yaşında bir erkek hasta sunulmuştur. Enjeksiyona bağlı olarak sol yanak, zigoma ve temporal alanlarda aniden ödem ve sellülit gelişmiştir. Erken drenaj ve antibiyoterapi sonrası hastanın şikayetleri gerilemiştir. Kısmi temporal kas nekrozuna ve fibrozisine bağlı olarak kesici dişler arası ağız açıklığı 15 milimetreye düşmüştür. Düzenli bir fiziksel tıp ve rehabilitasyon tedavisi ile bu açıklık ameliyat sonrası birinci yılda 35 milimetreye çıkmıştır.

Anahtar Kelimeler: Drenaj, kesici dişler arası ağız açıklığı, izoparafin C11-C15, ağız germe egzersizleri, portakal yağı

\section{INTRODUCTION}

Root canal treatment is a frequently performed dental procedure that treats periapical periodontitis (1). In case of failure, root canal retreatment is the most effective alternative (2). However, previously applied filling materials must be dissolved in order to reach the periapical region in the retreatment phase (3). As a natural essential fat, orange oil (isoparaffin $\mathrm{C} 11-\mathrm{C} 15$ ) is a solvent material that is able to dissolve the filling material very effectively (4). In this case report, a patient who had extensive subcutaneous left temporal necrosis after an inadvertent injection is presented and a management plan is proposed.

\section{CASE REPORT}

The patient was informed about each step of his treatment and he gave consent to all treatments and to the reporting of the case.

Corresponding author/iletişim kurulacak yazar: erol.kozanoglu@istanbul.edu.tr

Submitted/Başvuru: 28.03.2021 • Revision Requested/Revizyon Talebi: 17.04.2021 •

Last Revision Received/Son Revizyon: 22.04.2021 • Accepted/Kabul: 22.04.2021 • Published Online/Online Yayın: 12.11.2021 
After a left maxillary premolar tooth extraction, a 29 yearold male patient was referred to the Infectious Disease Department by his dentist who detected an immediate oedema and cellulitis formation in the left buccal, zygomatic and temporal region (Figure 1). The dentist reported an inadvertent subcutaneous injection of 5 milliliters of orange oil at the left gingivobuccal sulcus. The patient, who was an active cigarette smoker (10 packages/year), did not have any comorbidities in his medical history, he did not have any antibiotic therapy before tooth extraction, and severe paresthesia and erythema were found in the physical examination. The laboratory tests showed a neutrophilic leukocytosis, and blood culture was negative for any microorganisms before any antibiotics were given. Because of the presence of the necrotic regions, multidrug antibiotherapy with carbapenem, vancomycin, and clindamycin was administered in order to prevent any possible future infection and the patient was transferred to the Plastic Reconstructive and Aesthetic Surgery Department on the fifth day of hospitalization.

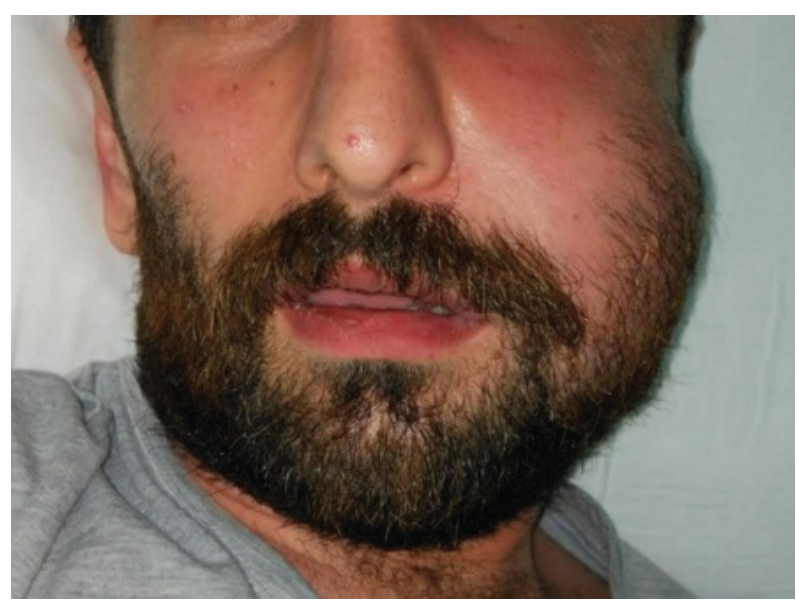

Figure 1: Oedema and cellulitis formation of the left buccal and zygomatic region are seen.

A fluctuation was detected in the left temporal region of the patient and left buccal mucosa was found to be affected by the same fluctuation during the intraoral examination. With a differential diagnosis of necrotic abscess, the patient was taken to the operating theatre promptly and dual drainage was performed. The left buccal region was drained through a transmucosal incision, whereas the left temporal region was drained through a transcutaneous incision. The purulent and necrotic exudate was removed and the total exudate volume was $125 \mathrm{cc}$. A Penrose drain was inserted in each incision and the patient was transferred to the ward. The patient was hospitalized for a week and manual drainage was continued through the Penrose drains. At the end of the hospitalization, exudative discharge ended and the drains were removed. The microbiologic tests found that the exudate was sterile and the pathological examination demonstrated extensive fat necrosis.
During the follow-up period, the interincisal mouth opening of the patient decreased to 15 millimeters at the first postoperative month (Figure 2). This change was thought to be caused by the pain that the patient had felt in his necrotic left temporal muscle when he tried to open his mouth. The patient was referred to the Physical Medicine and Rehabilitation Department. Mouth opening and active and passive stretching tests were advised and the patient was compliant with this treatment regimen. The patient was examined at the first year after hospitalization and the interincisal mouth opening was found to be 35 millimeters thanks to the precise physical therapy treatment that had been performed (Figure 3). The left tem-

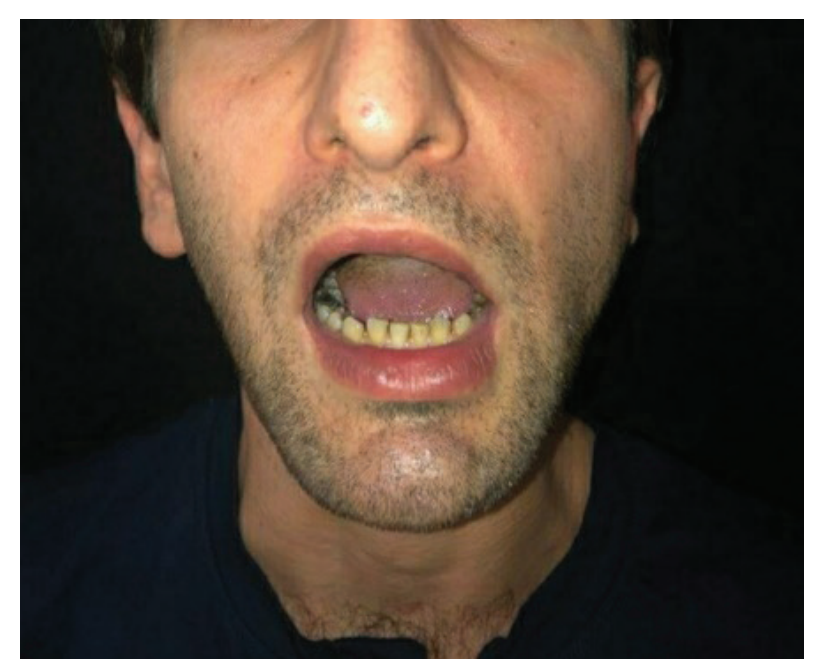

Figure 2: At the first postoperative month, the interincisal mouth opening of the patient decreased to 15 millimeters.

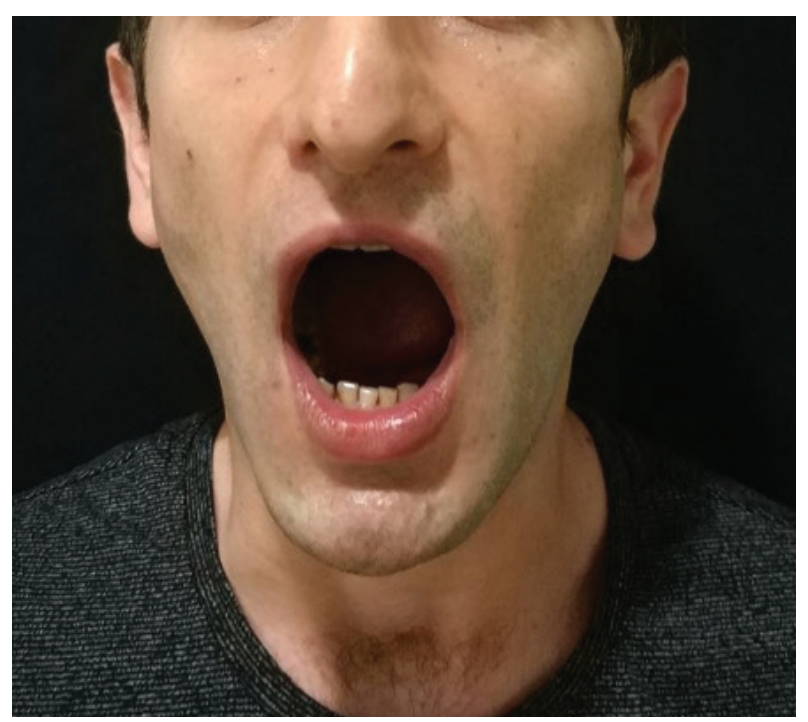

Figure 3: The patient is seen at the first postoperative year. The interincisal mouth opening is restored and no temporal asymmetry is detected. 
poral area was symmetric with the right temporal region and there was no need for any reconstructive procedures in order to restore the facial contours of the patient.

\section{DISCUSSION AND CONCLUSION}

Inadvertent subcutaneous injection of various solutions may cause an extensive necrosis in patients. Histolytic materials and solutions should be labelled and used with caution to prevent accidental in-vivo applications. Thorough information must be obtained about the physical and chemical properties of the insulting materials and immediate drainage should be performed in order to prevent permanent sequela. The importance of the patient's safety should always be kept in mind and the patient should be informed about the probable complications and other treatment options at the first referral.

Regardless of the etiology, physical medicine and rehabilitation measures should be kept in mind for the injuries and insults that affect the temporomandibular joint. These measures should be utilized as either a primary or an adjunctive treatment in this setting.

Informed Consent: Written consent was obtained from the participants.
Peer Review: Externally peer-reviewed.

Author Contributions: Conception/Design of Study- H.Ö.B., B.E.A., E.K., M.S., M.Y., U.E.; Data Acquisition- H.Ö.B., B.E.A., E.K., M.S., M.Y., U.E.; Data Analysis/Interpretation- H.Ö.B., B.E.A., E.K., M.S., M.Y., U.E.; Drafting Manuscript- H.Ö.B., B.E.A., E.K., M.S., M.Y., U.E.; Critical Revision of Manuscript- H.Ö.B., B.E.A., E.K., M.S., M.Y., U.E.; Approval and AccountabilityH.Ö.B., B.E.A., E.K., M.S., M.Y., U.E.

Conflict of Interest: Authors declared no conflict of interest.

Financial Disclosure: Authors declared no financial support.

\section{REFERENCES}

1. Yoneda N, Noiri Y, Matsui S, Kuremoto K, Maezono H, Ishimoto $T$, et al. Development of a root canal treatment model in the rat. Scientific Reports 2017;7(1):1-9. [CrossRef]

2. Duncan HF, Chong BS. Removal of root filling materials. Endodontic Topics 2008;19(1):33-57. [CrossRef]

3. Sarıyılmaz E, Keskin C. Evaluation of the effectiveness of three different solvents in dissolving gutta-percha and GuttaFlow: in vitro. Acta Odontologica Turcica 2017; 34(2):73-6.

4. Oyama KO, Siqueira EL, Santos Md. In vitro study of effect of solvent on root canal retreatment. Brazilian Dental Journal 2002;13(3):208-11. [CrossRef] 